DOI 10.31558/2519-2949.2018.1.5

УДК 328.185-048.66:323.212/.213(498)

Кабанцева І. А., Державний заклад «Південноукраӥнський національний педагогічний університет імені К. Д. Уиинського»

\title{
ГРОМАДЯНСЬКЕ СУСПІЛЬСТВО РУМУНІЇ: ДОСВІД ПРОТИДІЇ КОРУПЦІЇ
}

Автор досліджує процес подолання Румунією спадщини багаторічного тоталітарного гноблення на прикладі протидї̈ укоріненим корупиійним практикам у суспільно-політичному житті. Наголошено на важливій ролі в демократизачії Румунії ї̈ начіонального громадянського суспільства. Розглянуто динаміку громадянського активізму від 1989 р. Відзначено, що визначальний вплив на формування румунського громадянського суспільства мала жорстка форма авторитаризму періоду Н. Чаушеску, за якої елементи громадянського суспільства були практично відсутні. Автором підкреслено, що ия обставина відрізняла Румунію від інших тогочасних держав Центрально-Східної Європи (найперше Польщі та Чехословаччини).

Звернено увагу, щзо демократичний транзит у Румунії, рух до євроінтеграиії сприяв поступовому формуванню румунського громадянського суспільства, але водночас населення характеризувала низька громадянська компетентність, невиражений інтерес до політики та толерування корупиійним практикам. Проаналізована одна з перших великих акиій («Коаліція за чистий парламент», 2004 р.), результатом якої було визначення критеріїв до кандидатів у депутати румунського парламенту та зняття з виборів тих, хто не відповідав їм. Наголошено, що за умов непрозорої державної політики публічне викриття політиків стало дієвим антикорупційним механізмом, застосовуваним інституціями громадянського суспільства у співпраці з медіа. Констатовано, що на цей час громадянське суспільство було фактично рухом найактивніших румунських недержавних організаиій, але не охоплювало широкі прошарки населення та не залучало їх до неконвениійних форм політичної активності.

Відзначено, що румунське громадянське суспільство як спільнота, згуртована спільними інтересами колективного розвитку, пройшло чотири етапи становлення. Вони були зумовлені подіями, які викликали масовий народний протест: 1) виступи проти урядового проекту реформи охорони здоров'я (січень 2012 р.); 2) протести проти антиекологічного проекту Рош'я Монтане (вересень 2013 - лютий 2014 рр.); 3) антиурядові протести після пожежі в нічному клубі "Colectiv», зумовленої корупцією інспектуючих організачій (жовтень - листопад 2015 р.); 4) антикорупиійні антиурядові протести (січень 2017 - січень 2018 рр.).

Ключові слова: Румунія, громадянське суспільство, корупчія.

Новітні країни Центрально-Східної Європи третє десятиліття поспіль більш чи менш успішно долають спадщину багаторічного тоталітарного гноблення. Важливу роль у демократизації країн регіону відіграли молоді національні громадянські суспільства. Для України винятково цінним $є$ досвід демократичного транзиту держав-сусідів, зокрема й Румунії, позаяк динаміка громадянського активізму останніх років $є$ разючою. Ця держава обрана для дослідження з огляду на цінний для нас досвід румунського громадянського суспільства у його протидії корупції. Позаяк корупція та боротьба 3 нею є викликом для України, то вивчення досвіду інших держав зі схожим історичним минулим, зокрема Румунії, важливе в контексті пошуку дієвих антикорупційних механізмів. Українською політичною наукою ця тема лише починає досліджуватися (I. Кушнарьов, Г. Перепелиця, С. Федоренко та ін.).

В епоху соціалізму Румунія мала одну із найбільш замкнутих i авторитарних систем у Центрально-Східній Європі [16, с. 801]. Через надагресивний характер режиму Н. Чаушеску, у Румунії періоду оксамитових революцій в інших державах Центрально-Східної Європи («Осінь народів») громадянське суспільство було практично відсутнє. Навіть румунська православна церква була підконтрольна тоталітарній владі та не зуміла взяти на себе ту прогресивну роль, яку відіграли на початку транзиту демократії католицька церква у Польщі або ж лютеранська церква на східнонімецьких землях [1, с. 145]. Через переслідування режимом Н. Чаушеску творчої еліти, не сформувався критично налаштований прошарок соціуму, з якого виросли, до прикладу Хартія-77 у Чехословаччині, рух світських католиків і колишніх комуністів-інтелектуалів в Польщі 
і под. Прикладом обмеженого дисидентства можна уважати хіба що протести румунських гірників у 1970-х рр. [13].

Коли у 1989 р. відбулася Румунська революція (насильницьким, а не мирним як у більшості держав Центрально-Східної Європи шляхом), виник деякий вакуум: за масової підтримки нового ладу не було інституційних структур, які б прийшли на зміну старим. Створена після повалення Н. Чаушеску політична організація Фонд національного порятунку не змогла стати голосом громадянського суспільства, більшість його лідерів мали комуністичне минуле. Водночас, у більшості держав Центрально-Східної Свропи демократичні революції були підготовлені завдяки наявним елементам громадянського суспільства.

1990-ті - початок 2000-х pp. характеризувалися системною корупцією для Румунії. Корумпованим був як уряд, так і президент (Е. Константінеску (1996-2000) був змушений відмовитися від переобрання). Проблеми Румунії були типовими для посткомуністичних країн: державу поглинув великий бізнес, виборці мали низьку громадянську компетентність. Але довкола ідеї членства Румунії в ЄС, подолання перешкод євроінтеграції почало згуртовуватися новітнє громадянське суспільство. Напередодні вступу до ЄС Румунію розглядали як одну iз найкорумпованіших європейських держав, що ставило під сумнів можливість іï євроінтеграції. Хоч ще у 1996 р. Румунія вперше прийняла антикорупційне законодавство, але воно було недієвим. На виконання вимог ЄС Румунією у 2003 р. було прийнято пакет антикорупційних реформ, зокрема доступ до фінансових декларацій став відкритим, що створило передумови для обговорення громадянським суспільством за широкої підтримки медіа доброчесності державних службовців. Законодавчі нововведення стали для інституцій громадянського суспільства підмурівком для обгрунтування законності своїх реформаційних вимог. Саме тому в межах акцій, організованих громадянським суспільством, ні партії, ні політики не наважувалися відкрито протидіяти громадянському суспільству в його антикорупційних кампаніях.

У 2004 р. у Румунії було проведено масштабну антикорупційну кампанію, за результатами якої близько сотні депутатів зі сумнівною репутацією опинилися поза складом парламенту. Напередодні парламентських i президентських виборів-2004 румунське «громадянське суспільство вперше організувалося в широку коаліцію за чесність у політиці - Коаліцію за чистий парламент» [8]. Ініціатива Коаліції вийшла від Академічного Товариства Румунії. Ідею коаліційної протидії за чесність у політиці було запозичено у чехів; схожа кампанія проводилася й у Південній Кореї.

Критеріями до кандидатів на виборах-2004 було визначено: чи був кандидат співпрацівником спецслужби часів Н. Чаушеску «Секуритате» (до 1989 р.); як часто він змінював партійну приналежність і чи обіймав керівні посади в румунській комуністичній партії; чи мав кандидат конфлікт інтересів, найперше, під час приватизації, зокрема, чи не обіймав він високі посади, водночас ведучи бізнес; чи звинувачувався кандидат у корупції, шахрайстві, нецільовому використанні ресурсів; чи долучався кандидат до сумнівної приватизації державної власності; чи має кандидат приватні активи, які не відповідають поданій декларації; якщо кандидат на виборну посаду має бізнес, то чи не має його компанія боргів перед бюджетом; чи звинувачувався кандидат у кримінальних злочинах [11]. За результатами кампанії «Коаліція за чистий парламент» 98 кандидатів не були обрані через виключення з виборчих списків партій, але 104 пройшли; соціалдемократів на той момент було позбавлено панівного становища. I хоч кампанія була лише частково результативною, це була безумовна перша велика перемога румунського громадянського суспільства з очищення влади.

Ініціатива румунського громадянського суспільства увиразнилася розповсюдженням країною близько 2 млн листівок з остаточною редакцією переліку корумпованих кандидатів на виборні посади. Отже, акція була максимально озвучена задля активізації суспільства навіть у віддалених гірських районах Румунії. Довкола роздачі листівок згуртувалася ціла низка організацій, понад дві тисячі активістів-волонтерів. Акція 3 персональним зверненням до румунських виборців мала неабияке значення у ситуації, коли у 2004 році електронні соціальні мережі лише зароджувалися, та й загалом румунський сегмент Інтернету був дуже незначним. Проведені Коаліцією розслідування за підтримки значної частини медіа змогли налаштувати громадську думку проти політичного класу та його привілеїв.

Румунське громадянське суспільство показало: в умовах невмотивованості держави будувати прозору політику, публічне викриття $\epsilon$ дієвим антикорупційним механізмом інститутів громадянського суспільства у співпраці з медіа. Було відкрито низку кримінальних справ щодо запідозрених у корупції, запроваджено більш детальне декларування активів тощо. Серед інших важливих наслідків: 1) після виборів-2004 виникла низка «дочірніх» громадських антикорупційних 
спільнот - «Коаліція за чисті університети», «Коаліція за чистий уряд», діяльність яких теж слугувала цілям очищення румунського суспільства та держави від системної корупції; 2) почався експорт моделі коаліційної протидії громадянського суспільства у інші країни, найперше Центрально-Східної Свропи, наприклад, у 2006 р. утворено Громадянську кампанію «За чистий Європейський Парламент - Болгарія-2007»; 3) у 2007 р., коли Румунія вперше долучилася до виборів у Європейський парламент, кандидати у євродепутати були перевірені силами громадянського суспільства за низкою критеріїв [12], схожих до критеріїв, за якими проводилася перевірка на виборах 2004 р., згаданих вище.

Довший час (1989-2012) румунське громадянське суспільство було маргінальним, що можна пояснити спадщиною державного соціалізму. Неконвенційні форми політичної участі почали узвичаюватися аж від 2012 р. [16, с. 803]. Фактично до цього часу широкі народні маси не долучалися до вияву ініціатив та тиску на владу - такі дії виходили лише від нечисельних, але доволі потужних громадських об'єднань, підтримуваних Заходом.

На нашу думку, румунське громадянське суспільство як велелюдна спільнота, згуртована спільними інтересами колективного розвитку, пройшло щонайменше чотири важливі віхи свого становлення. Вони були зумовлені впливом подій, які викликали масовий народний протест:

1) виступи проти урядових заходів жорсткої економії (січень 2012; акції охопили 51 місто); поштовхом до виступів став проект реформи охорони здоров'я, який передбачав розширення платного медичного обслуговування;

2) протести проти проекту Рош'я Монтане (вересень 2013 - лютий 2014). Протести проти проекту Рош'я Монтане були спрямовані проти проекту видобутку цінних металів у шахтарському містечку Рош'ї Монтане, що мало б негативні наслідки для екології;

3) антиурядові протести після пожежі в нічному клубі «Colectiv» із численними людськими жертвами (2015). Нещасний випадок зумовив масові акції протесту, бо він стався саме завдячуючи адміністративній корупції (відсутність дозволу на роботу об’єкта, аварійних виходів, достатньої кількості вогнегасників тощо). Головним гаслом протестів стало «Корупція вбиває!»; це гасло стало об’єднавчим для різних суспільних груп. Ці протести «стали трампліном для багатьох представників громадського сектора, які на антикорупційній хвилі прийшли в політику» [2]. Відставка уряду (листопад, 2015 р.) соціал-демократів В. Понти, зумовлена тиском громадянського суспільства після протестів поклала початок справжній антикорупційній реформі: близько двох тисяч осіб були засуджені за зловживання владою;

4) антикорупційні антиурядові протести (січень 2017 - січень 2018). Це найбільші акції румунського громадянського суспільства від 1989 р. 3 огляду на те, що вони мали вузько антикорупційну спрямованість, зупинимося на них нижче детальніше.

Антикорупційні протести упродовж року можна систематизувати у три хвилі.

Перша хвиля (січень - лютий 2017 р.). Протести проти прийняття соціал-демократичним урядом постанови щодо пом'якшення антикорупційного законодавства (амністія та декриміналізація злочинів посадовців, засуджених за корупцію). Проти тих, хто завдав збитків державі на суму менш як 200 тис. леїв (47,8 тис. євро), передбачалося не відкривати кримінальні справи, а термін покарання за складніші корупційні злочини скорочувався зі 7 до 3 років. Уряд передбачав: амністувати засуджених за корупцію на терміни менш як 5 років (це близько 2,5 тис. осіб, зокрема й засуджені за політичну корупцію); заявити про корупційний акт можна було б не раніше, ніж за півроку від його вчинення. Фактично йшлося про декриміналізацію окремих корупційних правопорушень. Прийнята постанова допомогла б уникнути відповідальності за корупцію голові керівної Соціал-демократичної партії Румунії Л. Драгні, що дало б йому право претендувати на прем'єрську посаду; прийняття постанови уможливило б повернення до влади тих представників партії, які перебували під слідством. Зусиллями громадянського суспільства 05.02.2017 р. урядова постанова була скасована.

Друга хвиля (вересень - листопад 2017 р.). Протести проти озвучених урядом намірів ліквідувати політичну незалежність спеціального органу антикорупційного органу в судовій сфері Судової інспекції. Формування цього органу пропонувалося передати міністру юстиції. Уряд планував звузити повноваження глави держави (позбавлення права призначати керівництво прокуратури та Національного управління по боротьбі з корупцією). Натомість ці повноваження пропонувалися передати уряду в особі міністра юстиції. Такі зміни, заплановані румунським урядом, призвели б до політичного контролю в судовій системі.

Третя хвиля (січень - лютий 2018 р.) є продовженням вираження громадянським суспільством невдоволення політикою румунського уряду та суперечливим проектом реформи системи 
правосуддя. Законодавчі нововведення ускладнили б притягнення антикорупційними органами до відповідальності топ-корупціонерів. Протести призупинилися на тлі прийняття 30.01 .2018 р. Конституційним судом Румунії рішення щодо визнання неконституційними частини положень реформи сфери юстиції Румунії [9] та внесення вимоги до румунського уряду країни внести відповідні зміни до суперечливих положень проекту реформ.

I. Кушнарьов констатує, що саме завдяки ініціативному громадянському суспільству Румунією досягнуто значного поступу в мінімізації корупційних практик $[4$, с. 58], але за найменшого ослаблення контролю громадськості політична корупція намагається знову стати визначальною моделлю поведінки політичних акторів [5, с. 89]. Доказом цього й $є$ хвиля антикорупційних виступів 2017-2018 pр. На думку дослідника румунських протестів Ф. Поенару, вулична мобілізація стає дедалі важливішим чинником румунської політики [17]. Примітно, що сьогодні організація румунським громадянським суспільством антикорупційних протестів винесена найперше у соціальні мережі.

3 огляду на масові антикорупційні протести 2017-2018 pp. у Румунії не можемо у повній мірі погодитися 3 міркуваннями Я. Пилипа, що «Румунії вдалося створити ефективну систему боротьби проти корупції», а «причиною такого успіху, серед іншого, стала політична відданість керівництва Румунії боротьбі проти корупції протягом багатьох років» [7, с. 213]. Натомість у повній мірі згодні з О. Губрієнком, що не дивлячись на позитивні зміни у Румунії після вступу до ЄС, розвиток цієї держави «ускладнюється реліктами комуністичних режимів» [3]. Тоталітаризм так глибоко уразив Румунію, що залишив «спадок», відчутний навіть після майже трьох десятиліть демократичного транзиту та понад десятирічного досвіду членства у СС. Зокрема, в оприлюдненому на початку 2018 р. звіті органу Ради Свропи з боротьби з корупцією (ГРЕКО) [15] зроблено висновок, що Румунія досягнула дуже обмеженого прогресу в боротьбі з корупцією серед членів парламенту, суддів і прокурорів, а саме виконано уповні дві, частково - чотири зі загалом тринадцяти сформульованих у 2016 р. рекомендацій [14]. Основна з реалізованих ініціатив - прийняття у 2017 р. кодексу поведінки парламентарів (запобігання конфлікту інтересів, регулювання прийняття подарунків та інших переваг).

Саме тема корупції стала каталізатором громадянської активності в Румунії. Хоч після доленосних для Румунії подій 1989 р. корупція довший час не була стимулом до протестів знизу, але в останні роки наступило громадянське пробудження. Громадськість чітко ідентифікує корупцію як перешкоду успішній трансформації Румунії від соціалізму до демократії та капіталізму. Процеси, які відбуваються в Румунії у 2017-2018 pр., є показовим уроком, «як має діяти громадянське суспільство, коли політики намагаються використати владу як джерело одержання вигоди» [10]. Тому видаються цілковито обгрунтованими міркування українського дослідника-політолога Г. Перепелиці [6], який ставить Румунію прикладом Україні, позаяк ця країна та ії громадяни демонструють, як можна після тоталітарного режиму демократизовуватися, бути прийнятим до ЄС i НАТО. Румунський урок для України вбачаємо у тому, що громадянське суспільство не повинно лише спостерігати за створенням антикорупційних інституцій. Тільки, коли організована спільнота виходить на вулиці та починає вимагати справедливості й законності, влада може відступити від своєї непрозорої політики. Роль громадянського суспільства полягає у тому, що воно має бути на сторожі, щоб не відбувся реверс до корупційних практик у владі.

\section{Бібліографічний список:}

1. Авинери Ш. Партии, социально-культурная медиация и роль гражданского общества / Ш. Авинери // Полис. - 1994. - № 1. - С. 141-147.

2. Герасимчук С. Антикорупційний Майдан. Що спричинило масові протести у Румунії [Електронний pecypc]. - Режим доступу: http://www.eurointegration.com.ua/articles/2017/01/23/ 7060521/

3. Губрієнко О. Особливості політико-правових змін у країнах Центрально-східної Європи (на прикладі Болгарії та Румуніi) [Електронний ресурс]. - Режим доступу: http://www.stattionline.org.ua/filologiya/79/13419osoblivosti-politiko-pravovix-zmin-u-kra\%D1\% 97nax-centralno-sxidno\%D1\%97-yevropi-na-prikladi-bolgari\% D1\%97-ta-rumuni\%D1\% 97.html

4. Кушнарьов I. В. Інструменти боротьби з політичною корупцією у країнах Центральної та Східної Європи: оцінка ефективності на прикладі Румунії та Болгарії / І. В. Кушнарьов // Політикус. - 2017. - № 4. C. $58-61$.

5. Кушнарьов I. В. Політична корупція в Румунії: роль громадянського суспільства у протидії ій / І. В. Кушнарьов: Матеріали всеукр. наук.-практ. конф. (25-26 серпня 2017 р., м. Запоріжжя) [«Суспільні науки та сучасність: актуальні питання»]. - Запоріжжя : Класичний приватний університет, 2017. C. 89-93. 
6. Перепелиця Г. Боротьба з корупцією: румунські уроки для України [Електронний ресурс]. - Режим доступу: http:// uainfo.org/blognews/1486453321-borotba-z-koruptsieyu-rumunski-uroki-dlya-ukrayini.html

7. Пилип Я. Ю. Інституційні гарантії забезпечення прав і свобод громадян у сфері запобігання та протидії корупції за законодавством Румунії. Порівняльно-аналітичне право. - 2015. - № 5. - С. $213-217$.

8. Румунська Коаліція за чистий парламент. У пошуках чесності в політиці [Електронний ресурс]. Режим доступу: https://maidan.org.ua/2011/09/borotba-z-politychnoyu-koruptsijeyu-u-postkomunistychnij-evropi/

9. Сааков В. У Румунії суд оголосив неконституційною частину реформи юстиції [Електронний pecypc]. - Режим доступу: http://p.dw.com/p/2rnns

10. Федоренко С. Румунія: народ проти корупції [Електронний ресурс]. - Режим доступу: https://dt.ua/international/rumuniya-narod-proti-korupciyi-.html

11. Coaliţia pentru un Parlament Curat [Електронний ресурс]. - Режим доступу: www.sar.org.ro/coalitiapentru-un-parlament-curat-2004/

12. Coaliţia pentru un Parlament Curat - Alegeri Europene [Електронний ресурс]. - Режим доступу: http://sar.org.ro/coalitia-pentru-parlament-curat-2007-alegeri-europene/

13. Deletant D. Ceauşescu and the Securitate: Coercion and Dissent in Romania, 1965-1989 / D. Deletant. London : M.E. Sharpe, 1995. - 456 p.

14. Fourth Evaluation Round. Corruption prevention in respect of members of parliament, judges and prosecutors. Evaluation Report Romania [Електронний ресурс]. - Режим доступу: https://rm.coe.int/16806c7d05

15. Le Rapport de Conformité. Roumanie [Електронний ресурс]. - Режим доступу: https://rm.coe.int/quatrieme-cycle-d-evaluation-prevention-de-la-corruption-des-parlement/168077e15a

16. Olteanu T. The Romanian people versus corruption. The Paradoxical Nexus of Protest and Adaptation / T. Olteanu, S. Beyerle // The Open Journal of Sociopolitical Studies. - № 10 (3). - P. 797-825.

17. Poenaru F. Romanian protests: A cake with three layers (and a cherry on top) [Електронний ресурс]. Режим доступу: http:/www.focaalblog.com/2017/02/27/florin-poenaru-romanian-protests-a-cake-with-three-layersand-a-cherry-on-top/\#sthash.bah2qnKb.dpuf

\section{Kabantseva I. A. Civil society of Romania: the experience of combating corruption}

The author researches the process of overcoming the legacy of many years of totalitarian oppression by Romania on the example of counteracting the rooted corruption practices in all spheres of the social and political role. The important role of the national civil society in the democratization of Romania is emphasized. The study examines the dynamics of civic activism since 1989 and notes that the strict authoritarianism of the period of $N$. Ceaușescu rule, when the elements of civil society were practically absent, had a decisive influence on the formation of Romanian civil society. The author notes that this circumstance distinguished Romanian from the other Central and Eastern European states (especially from Poland and Czechoslovakia).

The article draws attention to the fact that the democratic transit in Romania and the movement towards European integration contributed to the gradual formation of Romanian civil society, but at the same time the population had a low civic competency, weak interest in politics, and tolerated corruption practices. It analyzes one of the first major actions ("The Coalition for a Clean Parliament", 2004), which resulted in determination of the criteria for the Romanian parliament candidates and withdrawal of those candidates who did not comply with them. It is emphasized that in the absence of transparent state policy, the public disclosure of politicians became an effective anti-corruption mechanism, used by the civil society institution in cooperation with the media. It is stated that at that time the civil society was in fact a movement of the most active Romanian non-government organizations, but it did not include the broad masses of the population and did not involve them in unconventional forms of political activity.

The author notes that the Romanian civil society as a community, united by common interests of collective development, has gone through four stages of formation. They were caused by the events that triggered massive popular protests: 1) protests against the government health care reform project (January 2012); 2) protests against the anti-environmental Roșia Montană project (September 2013 - February 2014); 3) anti-government protests after the fire in the Colectiv nightclub; 4) anti-government protests against corruption (January 2017 - January 2018).

Keywords: Romania, civil society, corruption. 